NEW STUDIES IN ETHICS

AXIOLOGICAL ETHICS 


\title{
Axiological Ethics
}

\author{
J. N. FINDLAY, F.B.A.
}

Clark Professor of Moral Pbilosophy and Metaphysics, Yale University 
(C) J. N. Findlay 1970

All rights reserved. No part of this publication may be reproduced or transmitted, in any form or by any means, without permission.

First published 1970 by

MACMILLAN AND CO LTD

London and Basingstoke

Associated companies in New York Toronto

Dublin Melbourne Jobannesburg and Madras

ISBN 978-0-333-00269-8 ISBN 978-1-349-00032-6 (eBook)
DOI 10.1007/978-I-349-00032-6 
CONTENTS

Editor's Preface vi

I. INTRODUCTION I

II. BRENTANO AND MEINONG I6

III. MOORE, RASHDALL AND ROSS 37

IV. SCHELER AND HARTMANN 57

V. FINAL SUGGESTIONS 78

Bibliography $\quad 93$ 


\section{EDITOR'S PREFACE}

Professor Findlay writes in this monograph: 'There really is, it would seem, an organised framework of values and disvalues within which our practical decisions must be made, and philosophy must give some account of the structure of this framework and of the principles guiding its construction.' He attempts to meet the philosophical need referred to in two ways. The views of some of the most important axiological thinkers are clearly and critically expounded. To this exposition the author adds his own opinions about value-theory.

The names of the authors to whom Professor Findlay refers are well known, but, with the exception of G. E. Moore, their writings are not now widely read, at any rate in places where analytical philosophy flourishes. Professor Findlay deplores this state of affairs. He considers, for example, that we should profit at least as much from a close study of the later chapters of Moore's Principia Etbica which make him 'one of the prime founders of axiology' as we do from our close study of the earlier chapters on the naturalistic fallacy which have made Moore 'the father of modern meta-ethics'. Whether the reader would agree with that or not, he will be most grateful for the clarity and learning with which the author of this monograph presents axiological ethics. He will find the pages which follow characteristically lively, forthright, readable and provocative.

Professor Findlay's exploration of this branch of ethics will guide students who know nothing of axiological ethics deftly through territory into which they might otherwise be deterred from venturing. Those readers who are familiar with this field will be particularly interested in the author's attempt to construct . a value-theory of his own. 